DOI $10.18413 / 2312-3044-2020-7-2-163-165$

\title{
Late Antiquity as a Transitional Period
}

\author{
N. N. Bolgov \\ Belgorod National Research University \\ Pobedy st. 85, Belgorod, 308015, Russia \\ bolgov@bsu.edu.ru
}

Copyright: (C) 2020 Bolgov, N. N. This is an open-access publication distributed under the terms of the Creative Commons Attribution License, which permits unrestricted use, distribution, and reproduction in any medium, provided the original authors and source, the Tractus Aevorum journal, are credited.

Opening the work of our round table devoted to late antiquity as a transitional era, I would like to note that this transition is of a classical nature for European civilization, just as antiquity itself is a classical civilization for the modern world.

Overall, scientists argue that the crisis of the 3rd century radically changed the ancient world. As a way out of this crisis, the surviving political organism of the empire acquired more solid military power with monarchist representations, as well as Christianity.

A number of questions arise about the chronological framework and the essence of the new political regime.

The lower boundary of the period is unambiguously associated with the restoration of the unified Roman Empire in 284 under the rule of Diocletian. A new flexible management system lasted about a century, until the power of Constantinople (the capital since 330) over the western provinces (476-486) was completely lost. After that, the Eastern Empire with varying degrees of success opposed external and internal challenges, stabilized, and from the VI century went on the counterattack, partially recovering the territories previously lost. The catastrophe befell the Eastern Mid-Sea region in the 630-640s, when the Arab-Islamic conquest led to the loss of Syria, Egypt, and then all of Africa. This coincided with the internal rebirth of the state under Heraclius.

Thus, it would be most correct to limit the era of late antiquity to the times between the 4th and early 7 th centuries.

The core of the late antiquity is somewhat more difficult to determine. The very first and indisputable point is a transitional character, transitivity.

ISSN 2312-3044 | http://belsu-tractus-aevorum.ru 
Virtually all the three and a half centuries the late antique society constantly evolved.

The base of the era was, of course, imperial statehood. The line of Roman statehood, which reached its peak in the 2nd century and exhausted the possibility of further expansion, was revived in the late 3rd century in almost the same territorial framework. The nature of power has changed somewhat. Today, a very outdated view of the establishment of a dominant regime at the turn of the 3rd-4th centuries as a kind of absolute (or absolutist) monarchy in the Orientalist sense is still widespread. And the new religion, Christianity, is considered to be its new spiritual and ideological foundation. But this view is now being actively revised.

The military-monarchist regime was not absolutism for a number of reasons. First of all, the empire retained the self-government of cities (municipal system), the main antique feature, due to which that civilization was, actually, still antique.

Further, absolutism is supposed to rely on the bureaucratic system and a strong state apparatus. But it was neither extensive nor excessive. The offices of Constantinople officials were supplemented by only a small apparatus of provincial government.

Groups of influence at the Royal Court, temporary rulers and favorites, began to appear under weak emperors only since the late 4th century, Regent Stilicho and his followers. Starting with the emperor Anastasius (late 5th century) they basically came to naught.

The military nature of the emperors' power is not questioned. Nevertheless, the tasks facing them changed following geopolitical trends. Throughout the entire 4th and half of the 5th centuries operational flexibility and mobility on the fronts and borders were important, which required tetrarchy, separation of powers, several metropolitan residences, etc. After the fall of the Huns, the situation changed significantly. The strengthening of imperial power in the 6th century led to a series of wars waged by the emperor Justinian for the restoration of the lost territories in the West. The political system of the empire gradually evolved, and we will not see clear borderlines between periods in the field of public administration.

The Christianization of the empire is often seen as an element of a new civilization poorly combined with antiquity. However, Christianity itself in the late antique period did not oppose the empire, but supplemented it. It crowned the emperors. The church adopted the administrative division of the empire. In cultural terms, the era of confrontation with secular (pagan) culture embraced only the 4th - early 5th centuries, and was eventually replaced by a period of intense contacts, mutual enrichment and, as a result, early Byzantine cultural synthesis of the 6th century.

The barbarization of the empire did not reach a critical level. The maximum approach of the barbarians to the heights of power took place around 400 in Constantinople (Gainas' plot). Subsequently, the resettlement of large masses of barbarians took place only in Western Europe, and the 
East (Byzantium) was able to adapt and absorb them, sending them mainly to the army, where they fought against external barbarians under Justinian.

The most important continuity tool was education and schools. The content of higher education remained mostly antique (philosophy, rhetoric, medicine, law). Only school management was Christianized.

The medievalization of knowledge, which was quite clearly manifested already in the 6th century, was not the result of either Christianization or barbarization. This was a consequence of the "old age" of antiquity, the exhaustion of its creative forces, closure within its framework, and a reduction in external contacts. The new picture of the world was not immediately established; among various groups of intellectuals, ethnic and confessional groups, various ideas about the world, its creation, or eternity coexisted.

High standards of socio-political and cultural life continued to remain basically unchanged until the Arab invasion.

One of the most important problems, which had not been resolved until the middle of the 7th century, was religious disputes. Trying to return the renegade Monophysite population of Syria and Egypt, the preChalcedonian churches of Armenia and the Christian East, Emperor Justinian made a compromise in the form of monophony. However, he did not achieve the desired result. In the fight against monothelitism, Maximus the Confessor and Pope Martin defended orthodoxy, and territories with the Monophysite population were lost as a result of Arab-Islamic conquests.

Thus, the end of late antiquity and the onset of the Middle Ages in the Eastern Mediterranean should be associated with a deep internal degeneration, a change in the military-administrative structure (the thematic system, exarchates, the reform of Heraclius), as well as the medievalization of culture. The state system of the empire did not undergo any fundamental changes, and the Christian church firmly blended into public life even in the framework of late antiquity. The Arab-Islamic invasion can be considered an important external frontier, coinciding in time with deep internal changes. 